\title{
Research on the Reform of Japanese-language Teaching Methods in College
}

\author{
Wu Fengjuan \\ School of Foreign Languages \\ Jilin Business and Technology College \\ Changchun City, China \\ 48212276@qq.com
}

\begin{abstract}
The development of the Internet has brought great changes to the educational leadership, and also greatly affects the way of Japanese language learning for college students. The author carried out grouping investigations and questionnaires on college students majoring in Japanese, and summarized the present situation and characteristics for students that using Internet in learning process. Furthermore, the author researched on the reform of the teaching methods by using the Internet technology, which needed the changes of teachers' duties and obligations and the cultivation of students' learning abilities independently.
\end{abstract}

Keywords-Reform; Japanese-language teaching; Internet; Autonomous Learning

\section{INTRODUCTION}

The development of the Internet has brought great changes to the educational leadership, and also greatly affects the way of Japanese language learning for college students. All kinds of Internet educational companies and websites emerge. New websites specially focus on the Internet education are set up. Meanwhile, some famous websites, such as HuJiang, Tencent and Sohu, have update the present software or services and add the Internet Education function. Therefore, the learning mode of college students has great changes under the influence of Internet technology. The teaching methods shall improve with the development of Internet technology. At the same time, with the globalization and the deepening of Sino-Japanese communication, the cultivation of senior talents majoring in Japanese is necessary and important to promote bilateral economic and cultural cooperation. Therefore, how to effectively use the Internet technologies in the present educational system? That is of great significance on the reform of Japanese-language teaching.

\section{INVESTIGATIONS AND QUESTIONNAIRES}

A. Courses for college students majoring in Japanese Language.

The majority of ordinary college Japanese professional training program will list the following courses for undergraduates: Japanese Intensive Reading (Japanese senior Japanese), Japanese listening, reading, grammar, writing, translation (Chinese-Japanese translation, Japanese-Chinese translation), Japanese Interpretation (simultaneous interpretation skills), and other compulsory or elective courses.

\section{B. Problems existed in the present classroom-teaching.}

The author will take the "Intensive Reading" as an example and analysis the problems existed. The author randomly chose 50 students from 5 universities, and delivers 50 questionnaires on the present's situation of Japanese-language teaching in college to students in Shan'xi Normal University, Northeast Normal University, Liao Ning University, Jilin University. 46 of questionnaires are valid and recovered. The results are as followed.

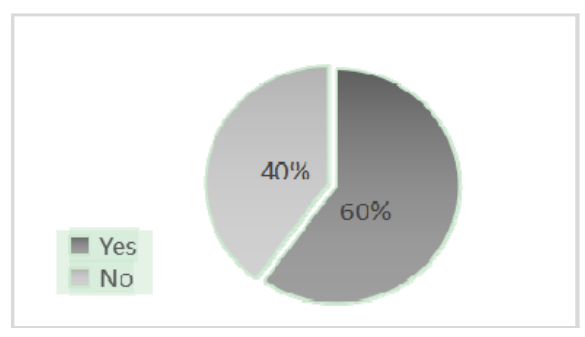

Fig. 1. The Usage of multimedia devices and Internet resources

According to the result of the questionnaires, Figure 1 shows that the majority of teaching staff use the multimedia devices and internet resources in the classroom-teaching.

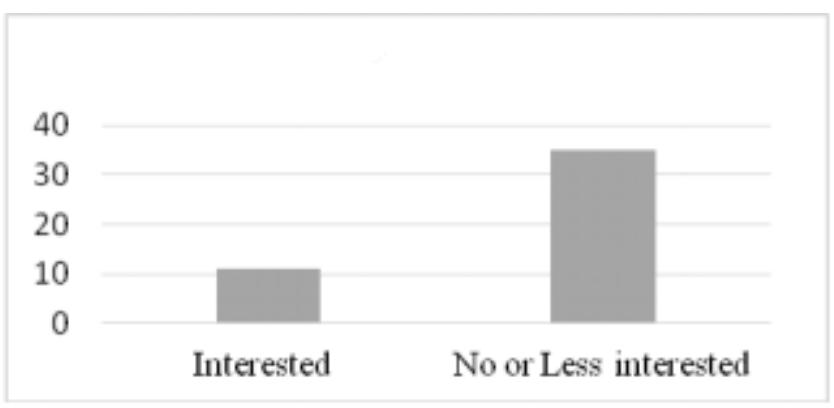

Fig. 2. Does teaching materials in class successfully attract you?

According to Figure 2, we could draw the conclusion that the majority of teaching staffs fail to attract students by using multimedia devices and Internet resources due to various factors at present. 
According to Table 1, we could find the disadvantages of the present classroom-teaching from the perspective of students.

TABle I. Disadvantages of the Present ClassRoomTEACHING

\begin{tabular}{c|c|c|c}
\hline No. & Item & No. & Proportion \\
\hline 1 & $\begin{array}{l}\text { Rigidly adhere to textbooks, not } \\
\text { job-oriented. }\end{array}$ & 15 & $32.6 \%$ \\
\hline 2 & $\begin{array}{c}\text { Lack of consideration of } \\
\text { individual differences of } \\
\text { students. }\end{array}$ & 8 & $17.4 \%$ \\
\hline 3 & $\begin{array}{c}\text { Traditional teaching mode is } \\
\text { dominant. }\end{array}$ & 13 & $28.2 \%$ \\
\hline 4 & Lack of interaction. & 4 & $0.8 \%$ \\
\hline 5 & Teaching spaces are limited. & 6 & $13.0 \%$ \\
\hline
\end{tabular}

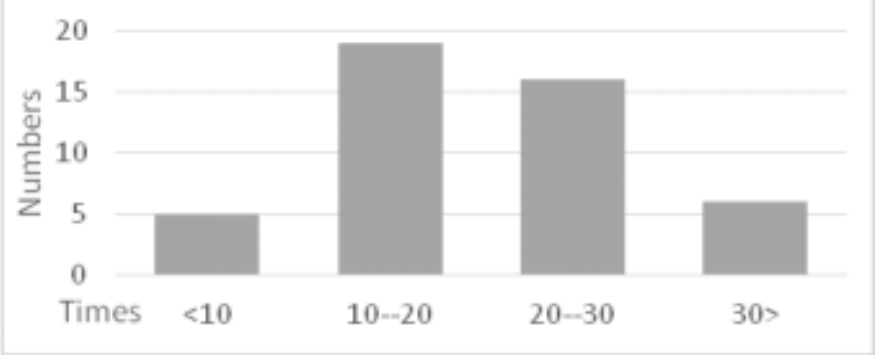

Fig. 3. Utilization of the Internet learning Resources.

According to the questionnaire, 41 students use the internet quite often if we define "often" at a frequency of 140 times a week, accounting for $89.1 \%$ of the proportion of the survey. It shows that college students are closely connected to the Internet.

However, according to Figure 3, college students are not quite often to use the learning resources on the internet. 19 of the total 46 students use the learning resources on the internet 10 times to 20 times each week, accounting for $41.3 \%$ of the proportion of the survey. And 16 students use the learning resources on the internet 20 times to 30 times each week, accounting for $34.8 \%$. Only $13.0 \%$ of students use the internet learning resources above 30 times each week. The result shows that students not use the learning resources efficiently on the Internet, which needs further guidance.

\section{The Present Situation of JaPanese-Language TEACHING IN COLLEGE.}

With the globalization and the deepening of Sino-Japanese communication, the cultivation of senior talents majoring in Japanese has become increasingly necessary and important. The traditional teaching methods has sometimes failed to meet the needs because of its disadvantages such as closure,hysteresis quality and separation.

Firstly, most of the Japanese language teaching in colleges and universities is dominated by teachers, according to the fixed Japanese-language teaching materials. This teaching mode restrained the students' autonomy of learning to a certain extent. One of the important principles in language learning is to stimulate students' interest in the language. The traditional teaching method is obviously not able to promote the students' motivation of learning.

Secondly, the traditional teaching materials rigidly adhere to textbooks, and are closed and not job-oriented. Take "Writing" and "Conversation" courses a examples, the contents are limited to the daily life, not including or rarely relating to the scene of business, tourism, hospitality, mails. And this situation is particularly obvious in comprehensive universities. Because of the limited number of students and lack of times, the design of course and teaching materials is Lack of consideration of individual differences of students. Besides, many new expression and vocabulary are absent, which will easily let the students feel very boring to learn Japanese and refuse to learn.

Thirdly, many teaching staff in college fails or can not efficiently uses the Internet resources and multimedia. It's a ideal solution to study in a speech classroom or multimedia classroom, due to the special features of foreign language teaching materials. However, it is difficult to satisfy the objective requirements mentioned above for multimedia teaching even for colleges in "211 list". In addition, the teachers can not efficiently use the present Internet resources.

Finally, the class teaching and the students' learning after classes is strictly separated in the traditional teaching mode. It is difficult to form an open large-scale learning community because of the lack of interaction between teachers and students and the lack of students' extra learning. Therefore, it is definitely the key on the reform of Japanese-language teaching by combing the Internet technology with the traditional classroom teaching mode.

The Internet teaching mode based on the Internet, which enables each student easily connect to the web learning resources and learning community. Students have access to the latest trend of the society and the knowledge. The characteristic of opening gives students the great learning autonomy and freedom of study. The Internet teaching mode enables the students easily communicate and interact with each other's. Besides, learning groups will be set up, which will bring online and offline activities and effectively promote the language learning. Finally, the development of Internet learning software and websites enable students to access to the learning materials whenever and wherever by mobile phones, computers and other facilities, which let the Internet learning mode extend to the every parts of learning.

However, there are some irreplaceable advantages of the traditional teaching method. In the current teaching system, it is difficult to introduce the internet teaching mode into the university classroom teaching because of the various aspects such as the expenses limitation and teaching plans. But we could properly introduce the Internet technology into the present teaching system in order to reform the teaching method. 


\section{THE ReForm OF THE TEACHING METHOD}

As mentioned above, we shall introduce the Internet technology into the present teaching systems, which will greatly enlarge the horizon and cultivate the learning abilities of the students .Besides, with the increasingly fierce competitions, learning is not only important on campus. The good learning habit and methods and the long-lasting learning intention are all necessary for senior talents. Therefore, how to help and guide the students to effectively use the Internet technology and learning sources and cultivate the independent learning abilities are the urgent affairs of the reform of Japanese-language teaching. The author believes that the reforms shall be conducted in the following respects:

\section{A. The Transformation of Teaching Ideas}

The traditional foreign language teaching is based on the teacher-leading principles, which students passively accepts the knowledge and are lack of practices. In this mode, students' autonomy of learning is restrained, and they become increasingly rely on teachers. Therefore, the key to create an independent and independent learning atmosphere is the teacher. Therefore, a teacher shall firstly change the teaching idea, and change the role of a simple introducer and conductor. In the new trend, a teacher shall be an organizer, a guider and meanwhile a manager of the teaching platform.

It is very important for teachers to cultivate students' independent learning habits and confidence, and teach students how to learn. With the motives and methods, students will learn automatically. When learning becomes a habit, the academic records are consequently improved.

Teachers shall learn the usage of the internet on the basis of a clear based on grasp of the teaching goal and the teaching schedule. Teachers shall flexibly use resources from internet in the teaching process, and meanwhile keep up with the trend of the Internet, and guild students correctly and effectively use the information and methods from internet. Teachers could select the proper materials of Japanese learning from the internet and recommend learning websites and database to students. In conclusion, teachers play crucial roles in the Internet Japaneselanguage teaching, which shall connect the Internet education to college education and promote the cultivation of senior talents majoring in Japanese.

\section{B. The Cultivation of Students' Consciousness of Autonomous Learning.}

The core of self-conscious and well-motivated modern education is to develop the students' consciousness, habits and abilities of autonomous learning. In order to achieve this target, teachers shall follow several methods.

Firstly, teachers should take the idea of autonomous learning into teaching, use a variety of effective forms and methods to arouse the students' motivation, initiative and creativity. Once the consciousness of independent learning is aroused, a student will change the role of a passive receiver of knowledge into a active learner. Secondly, teachers shall inspire the students' learning interests and encourage their independent learning spirits in the process of guiding students' autonomous learning. Third, when students encounter various difficulties and problems in the process of learning, a teacher shall take an equal, democratic, understanding, caring, appreciative attitude towards the students, inspire and guide them to solve problems independently, and cultivate their abilities of analyzing and solving problems independently. At the same time, teachers shall actively take part in learning activities and share their opinions or provide solutions of problems with students. In this process, a good and harmonious relationship between teachers and students is established through the interaction, which will consequently strengthen the ability of autonomous learning of students.

\section{To Cultivate Students' Autonomous Learning Ability in Classroom Teaching}

The classroom is the main platform for teaching. The classroom teaching has a very important influence on the cultivation and improvement of students' autonomous learning ability.

Teachers shall change the teaching strategies from "teaching" to "learning" in the classroom, and organize the teaching basing on "self-exploration and discovery ", in which process arouse students' enthusiasm and motivation in learning.

Teachers shall not only teach the academic knowledge of the language learning, but also make students effectively participating in the teaching process through the brilliant design of various activities and exercises, in which process that students' autonomous learning conciseness and habits are cultivated.

\section{To Establish a Reasonable Evaluation Mechanism}

The administrative department of education shall change the evaluation mechanism on the teaching quality of teachers and academic achievements of students, and establish an incentive mechanism on independent study. Teachers shall understand the situations of students' autonomous learning and existing problems. Elements such as the quality of homework on the internet, the quantity of participation on BBS discussion, the depth and breadth of thinking in the communication, and the vividness and accuracy of language expression, shall be the assessment indicators in the new mechanism. The situations of autonomous learning on internet mentioned above, the performance on the class and the results of the final exam constitute the entire elements of the new evaluation mechanism.

The administrative department of education shall monitor the whole process of Internet teaching, encourage teachers effectively use the modern teaching technologies and improve the efficiency of using internet teaching platform.

\section{CONCLUSIONS}

The development of the Internet promotes the reform on the traditional Japanese-language teaching in college. How to effectively introduce the methods and thinking of internet teaching into the present teaching system in order to promote the teaching reform, is a long-term project worthy of our great efforts and deep Research. 


\section{REFERENCES}

[1] Zhang Xiaoxi, Research and investigations on new pattern on the primary of Japanese-language teaching in Chinese[J],Study and Research on Japanese, 2005.

[2] Mo Jinguo, Theory and Practice on E-learning of Foreign Language in Chinese[M],Shanghai Foreign Education Press, 2001,37.

[3] Tang Qingan et. The Designing and Practice of Internet Classes in Chinese[M]. People Youdian Press, 2003.
[4] Zhu Cuier, Japanese-language teaching under the Internet Learning in Chinese [J],China Technology Information, 2006(03).

[5] Wen Yujing, Analysis on the Reform of Japanese-language teaching Pattern in Chinese[J], Reading, 2016(20).

[6] Wang Dehua, Teaching and Learning under the Internet in Chinese[M], Southeast China University Press, 2003. 